\section{LIVER TRANSPLANTATION FOR WILSON'S DISEASE}

SIR, - We have reported before on the early coursc two patients after liver transplantation for Wils disease. ${ }^{1.2}$ The indication for operation in the fitst recipient was liver failure. This boy, who is now aged 17 years, will be six years post-transplantation on July 15 . 17 years, will be six years post-transplantation on July ment. With the pronstrated, mainly by a prolonged cupriuresis. However, the potential usefulness of the cupriuresis. Howtions in the context of Wilson's disease and its treatment was reduced by certain atypical features of the case. Although the copper concentration in the native liver was very high, the serum caruloplasnin concentration was low normal and the corneas had, evidence of Kayser-Fleischer rings.

The second patient is now four years two mon: s post-transplantation.

He was first diagnosed as having Wilson's disease at the age of 11 years. By the age of 14 years, he had progressively deteriorating st, as a paranoid that he had no . After years of ompensation for success and the have frightened s to make it clear pitous wholesale morrow, and that such discharges. exactly what is c asking what is can be done in under the threat entally ill patient utside is held in tally ill patient is 3 outraged public n-dangerous are $s$.

$n$ of whether a be involuntarily is offered. That squate treatment, iponsive patient. use who have to ave a legal right ight to releaseing against their in be argued that and indeed the that good health illnesses, mental ich " treatment" vasteful. Has a adequate treatWith increasing the mentally ill $e$ an increase in public emotions Some people see :mocracy and of : clumsy fashion, islative bodies to :rvants carry out eans for them to nctions that the

BIOCHEMICAL FINDINGS BEFORB AND AFTER TRANSPLANTATION 2.9 8. per $100 \mathrm{ml}$., respectively. He showed no respo only slightly above normal (see table).

biopsies appeared normal histologically. Halgrimeon, C. G., Schroter, G., Star ment. With the provision of a new liver, a decoppering

Initially, ceruloplasmin was virtually absent in the serum of this patient, but within three months after transplantation it focreased dramatically and now remains normal (see table). The ferum-copper concentration, which was low preoperatively, sypidly increased early postoperatively, then fell to normal.

Fostoperatively, the parient's neurological dysfunction has Ifradually improved and now he has no neurological impairment. xp The Rayser-Fleischer rings have completely disappeared over a ayod of two and a half years as determined by several slit-lamp T. Sise classical clinical manifestations and biochemical Wnormalities of Wilson's disease has not been reported ith other forms of therapy. ${ }^{3}$ These observations lend Iupport to the contention that this genetic disorder is With-based. With the provision of a normal liver, excess \% ody-copper is eliminated over a period of years.

This work was supported by research grants from the Veterans Fininistration; by grants AI-AM-08898 and AM-07772 of the itecional Institutes of Health; and by grants RR-00051 and IB-0069 from the General Clinical Research Centers Program

\begin{tabular}{|c|c|c|c|c|c|}
\hline \multirow{2}{*}{ 一 } & \multirow{2}{*}{$\begin{array}{l}\text { Normal } \\
\text { values }\end{array}$} & \multicolumn{4}{|c|}{ Relation to operation } \\
\hline & & Preop. & $\begin{array}{l}3 \text { mo. } \\
\text { postop. }\end{array}$ & $\begin{array}{l}17 \text { mo. } \\
\text { postop. }\end{array}$ & $\begin{array}{l}42 \text { mo. } \\
\text { postop. }\end{array}$ \\
\hline $\begin{array}{l}\text { Liver-copper } \\
(\mu \mathrm{H} / \mathrm{g} \text { ) }\end{array}$ & $<20$ & 184 & 一 & 45 & $2:$ \\
\hline $\begin{array}{l}\text { Serum-copper } \\
\text { (118./100 ml.) }\end{array}$ & $70-118$ & $22 \cdot 4-35$ & 149 & 74 & 73 \\
\hline $\begin{array}{l}\text { Ceruloplasmin } \\
\text { (mg./100 ml.) }\end{array}$ & & $1 \cdot 0-1 \cdot 7$ & 74 & 48 & 32 \\
\hline $\begin{array}{l}\text { Urine copper } \\
(\mu \mathrm{g} / 24 \mathrm{hr})) \\
\text { s.0.0.T. (1.0./1.) }\end{array}$ & $\begin{array}{r}<30 \\
3-27\end{array}$ & $\begin{array}{r}540 \\
25\end{array}$ & $\begin{array}{r}119 \\
70\end{array}$ & $\begin{array}{l}80 \\
25\end{array}$ & $\begin{array}{l}87 \\
15\end{array}$ \\
\hline $\begin{array}{l}\text { Serum-bilirubin } \\
\text { (mg./100 ml.) }\end{array}$ & $<1.0$ & $2 \cdot 9$ & 0.4 & 0.64 & 0.5 \\
\hline
\end{tabular}

hepatic and neurological function. Although be had ascites, hepatic and seurological funded more because of the sericus transplantation was recommended more becasse of the He ! id neurological impairment than because of liver fallure. There is re crippling dystonia, dysarthria, and choreoatbetosis. There it prominent Kayser-Fleischer rings. Liver-function tests inclu do a serum-bilirubin of $2.9 \mathrm{mg}$. per $100 \mathrm{ml}$., a prothrombin-tim of $44 \%$, and serum protein and albumin concentrations of 5.7 showed no response to

D-penicillamine and triethyltetramine dihydrochloride.

On March 23, 1971, orthotopic bepatic transplantation was carried out. Postoperatively, immunosuppression included), cyclophosphamide (for which azathioprine was later substituted), prednisone, and a three-month course of beterologous antilymphocyte globulin. Present

accompanying table).

As previously reported," his liver removed at transplantation had a markedly increased copper content (see table). Biopsies of the homograft at twelve, thirteen, and seventeen months are transplant showed tissue-copper leveis of 48,30 , and $45 \mu \mathrm{g}$. per 8 . wet weight, respectively. In the most recent biopsy at forty- vo months, the tissue-copper level was 27 H8. per 8 . Wet weigl aft

1. DuBois, R. S., Giles, G., Rodgerson, D. O., Lilly, J., Martineau, G.,

Sheinbers, I. H. Lances, 1971, i, 505.

Groth, C. G., DuBois, R. S., Corman, J., Gustafsson, A., Iwatsuke, S., Rodgerson, D.
Proc. $1973,5,829$.

Iondon WIM TDR.

Adams, A. H. D., Waters, M. F. R. Br. med. J. 1966, ii, 892
The complete correction, in our second patient, of all the Division of Research Resources, National Institutes of inith.

FU

SIR,editorial pathology at the $\mathrm{cr}$ changes a where chi pathologic important

Perhaps problems philosoph are neede cope with highly sop develop in qualified and at the so that on and he has at the beds lems such

lipidamia,

biochemica priate tests. clinical anc fulfilled by together wi. pathology general pat! training, a It is surely clinical mec

The cher probably b. chemist anc responsibilit intensive $\propto$ controlling . district gent vital clinical type of app: already taki. aware of th chemical pa. exciting, rew in clinical $\mathrm{m}$

University I
Chemical P
Human A
General
South-
Baningstoke
Hospita: While Dr Pearson and his colleagues state that "the "3 duration of treatment before relapse is very striking ", cite one patient who relapsed after only 5 years of i-mittent treatment, it should be known that, in a Ferian patient, relapse due to dapsone-resistant organisms Fured after 52 months of regular treatment at a dose of ing. twice weekly."

Fortunately, no case of relapse due to sulphone-resistant onisms has so far failed to respond to clofazimine."

Xeprony Study Centre.

757 Wimpole Street.

S. G. BrownE.

Bearn, A. G. in The Metabolic Besis of Inherited Disease (edited by J. B. Stanbury, J. B. Wyngarden, and D. J. Fredricloson); p. 1033. New York, 1972

Browne, S. G. Int. J. Leprosy, 1969, 37, 296

Browne, S. G. Trans. St. John's Hosp. dorm. Soc. 1973, 39, 225.
SIR,-Your that there mu and renewal collaboration I think by alo ing this year clinical bioch indeed many tions. The establishment

For the pas staffing on a non-medical the whole of 